\title{
ばね用洋白線の加工および焼鈍しによる疲労強さについで
}

\author{
西畑三樹男** 山浦 將 甫***
}

\section{The Effects of Cold Drawing and Annealing on the Fatigue Strength in Nickel Silver Wire}

by

\author{
Mikio NisiHata and Masatoshi Yamaura \\ (The Electrical Communication Laboratory)
}

The study was carried out on the variation of the fatigue strength and the mechanical properties: due to cold drawing and annealing for the specimens of nickel silver wire.

The specimens were cold drawn and straightened again into $2 \mathrm{~m} / \mathrm{m} \phi$, and Haigh-Robertson testing machines were used for the fatigue test.

The followings are the results obtained:

(1) Due to cold working the nickel silver wire was increased in tensile strength, yield' strength, spring limlt, hardness, and fatigue strength, but, on the contrary, decreased in elongation. The number of torsion attained to the maximum when the specimens were reduced to $20 \%$.

(2) Low annealing effects do not make the fatigue strength increase for the cold drawn and straightened specimens. Especially, in the case of low drawn wire materials, the mechanical properties and fatigue strength will decrease with annealing temperature. As for high drawn wire, the mechanical properties and fatigue strength whose values are lower than those which are not low annealed were increased at $250 \sim 350^{\circ} \mathrm{C}$.

(3) The value of the fatigue ratio of the nickel silver wire was 0.35 when cold drawn and approximately 0.25 when low annealed.

(4) The value of spring limit corresponds to the value of yield strength which may be calculated from the results of tension tests.

(Received Sep. 3, 1960)

\section{1. 緒}

洋白は周知のようにばね材料として広く用いられて おり，板ぼね材料としての加工，熱処理による機械的 性質および耐疲労性については, かなりよく調べられ ている.しかし，線ばね材料としての機械的性質や耐 疲労性について調べたものはきわめて少ない。したが って, 洋白線材の加工, 熱処理による機械的性質なら びに疲労強さについて一連の実験を行なうことは工学 上有意義のことと思われる。そこで著者らは $2 \mathrm{~m} / \mathrm{m} \phi$ の直線性加工した洋白線の加工および焼鈍しによる機 械的諸性質と疲労強さについて実験を行ない, 耐疲労 性について検討した。 その実験結果について報告する。

\section{2. 実験材料および実験方法}

\section{(I) 実験材料}

Table 1 にその化学成分を示す．加工度は $20,60 \%$ の 2 種類で, 最終線径 $2 \mathrm{~m} / \mathrm{m} \phi$ に線引加工後, 所定の 直線性加工を施したものである.

\footnotetext{
* 原稿受付 昭和 35 年 9 月 3 日

** 正員 日本電信電話公社電気通信研究所

***** 日本電信電話公社電気通信研究所
}

\section{(II) 低温焼鈍}

加工度 $20,60 \%$ 試料について $200 \sim 400^{\circ} \mathrm{C}$ まで $50^{\circ} \mathrm{C}$ おきの温度で, アルゴンふんい気中にて $60 \mathrm{~min}$ 焼鈍 し, 空冷した. (常温 $10 \mathrm{~min}$ 所定温度 $\times 60 \mathrm{~min} \underset{10 \mathrm{~min}}{\longrightarrow}$ 常温).

(III) 引張強さ, 伸び, 耐力の測定

$\mathrm{XY}$ 伸び記録計を取りつけたアムスラー引張試験機 により引張強さ, 伸び, 耐力を求めた。耐力は $\mathrm{XY}$ 伸 び記録計より応力ーひずみ線図を描き， $0.2 \%$ 永久ひ ずみの生じた応力をもって表示した。

(IV) ばね限界值 $\left(\boldsymbol{K}_{\boldsymbol{b}}\right)$ の測定

ばね限界值とは, 片持はりの自由端に荷重を遂次階 段的に増加して与え，それによって生ずる自由端の永 久変形量を測定し, その大小によってばね材料の良否 を判定するものである。 その試験機は Fig. 1 に示す

Table 1 Chemical composition of specimens (\%)

\begin{tabular}{c|c|c|c}
\hline Components & $\mathrm{Ni}$ & $\mathrm{Zn}$ & $\mathrm{Cu}$ \\
\hline WA-NSW & 18 & 27 & 55 \\
\hline
\end{tabular}


とおりで, 試験片に繰返したわみを与えるためには, 引掛け金具 $(\mathrm{S})$ を接触させてから偏心ローラー (D) を モーターにより回転させる。この偏心ローラーは，第 1 ステップが $4 \mathrm{~mm}$, 以下階段的に第 10 ステップの 16 $\mathrm{mm}$ までの変位を試験片の自由端に与えるようになっ ている. 試験はこの各ステップごとに50回の繰返し を与え, そのつど試験片の自由端の永久変位量を望遠 鏡により测定し，その変位が $0.1 \mathrm{~m} / \mathrm{m}$ に達した時の 最大表面応力をもって表わす。この応力は通常 $K_{b}$ な る記号で表わし, 次式で与えられる. $K_{b}=3 d E f / 2 l^{2}$

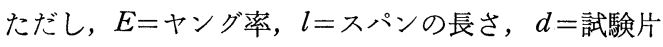
の直径, $f=$ 変位量, この実験は $E=13000 \mathrm{~kg} / \mathrm{mm}^{2}$, $l^{2}=4000 d$ とした.

\section{（V）かたさの測定}

ライツ製微小かたさ試験機荷重 $200 \mathrm{gr}$ を用い, 線径 の横断面について測定した.

\section{(VI) ねん(捻)回値の測定}

手動式ねん回試験機を用い, 標点距離 $50 d$ で測定し, その值をいずれも $100 d$ に換算して表わした.ねじり 速度は毎分約 60 回，軸方向引張荷重は $2 \mathrm{~kg}$ とした。

(VII) 疲労強さの測定

Fig. 2 に示すへイ・ロバートソン式繰返曲げ疲労試 験機を用いた．そのときの回転数は 毎分約 4000 回， 標点距離は $100 d$, 応力計算に必要なヤング率は, 加 工材および低温度焼鈍材とも $13000 \mathrm{~kg} / \mathrm{mm}^{2}$ とした。

\section{3. 実 験 結 果}

\section{（I）冷間加工材の機械的性質}

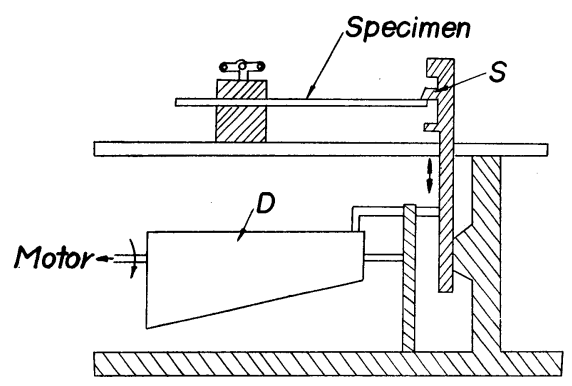

Fig. 1 Schematic illustration of the testing machine for the measurement of $K_{b}$

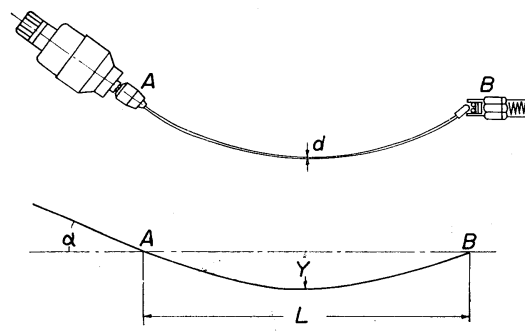

Fig. 2 Principle of the Haigh-Robertson testing Machine
Fig. 3 は加工度 $0 \%\left(600^{\circ} \mathrm{C} \times 1 \mathrm{hr}\right.$ 焼鈍材 $), 20,60$ \%の引張強さ, 耐力, 伸び, ばね限界值の結果を示す. これによると引張強さ, 耐力, ばね限界值はいずれも 加工とともに増加し，伸びは逆に減少している．特に ばね限界值は耐力とかなりよく一致した值を示してい る. Fig. 4 は, 各加工度の応力ーひずみ線図を示した ものでこれによると各試料とも耐力付近に明らかな のこぎり歯状降伏現象がみられ，そのでかたは加工度 が大きいほどより明りょうに現われている．Fig. 5 は

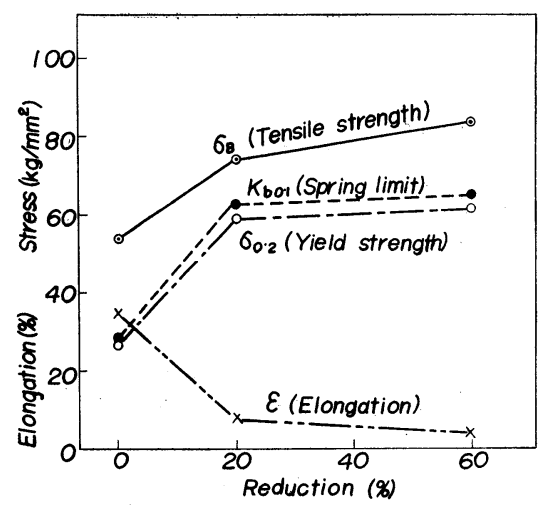

Fig. 3 Relations between the degree of reduction by cold drawing and the values of $\sigma_{B}, \sigma_{o \cdot 2} K_{b}$ and $\varepsilon$

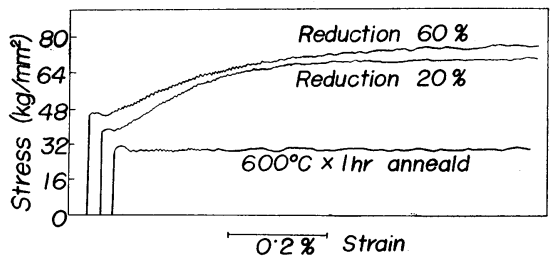

Fig. 4 Stress-strain curves of nickel silver wire

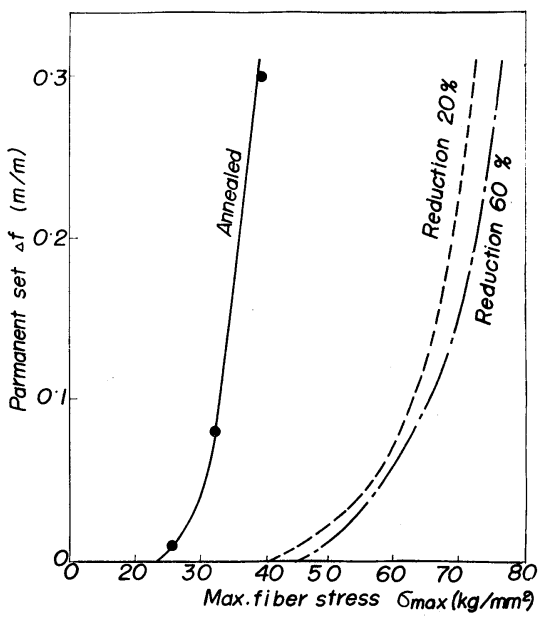

Fig. 5 Relation between $\Delta f$ and $\sigma_{\max }$ 
ばね限界值を求めた応力ーたわみ曲線の一例である。

Fig. 6 の硬さ值は加工とともに増加しており, その分 布は $20 \%$ 加工のものは線の中心部より表面が低く， 60\%加工のものはかたさ対中心よりの距離の曲線が二 重山形の傾向に変わっている．これは線引加工および 直線性加工の影響によるためと思われる．Fig.7 のね ん回值は加工度 $20 \%$ 付近に最大值を示すところがある。

\section{(II) 冷間加工材の疲労強さ}

Fig. 8 は加工度 $0,20,60 \%$, 試料の $S-N$ 曲線を

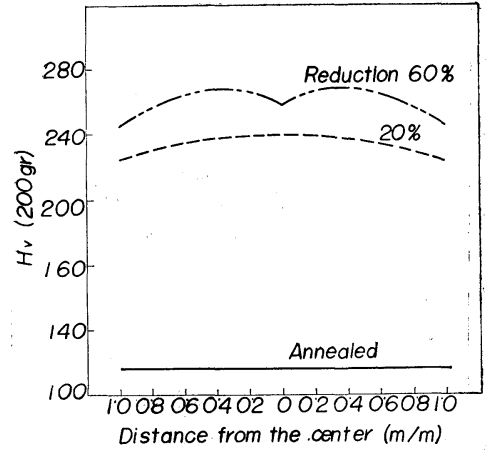

Fig. 6 Hardness distribution on the cross section of the specimens used

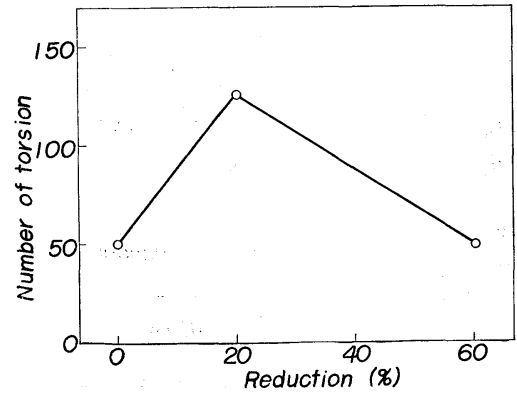

Fig. 7 Relation between the degree of reduction by cold drawing and number of torsion

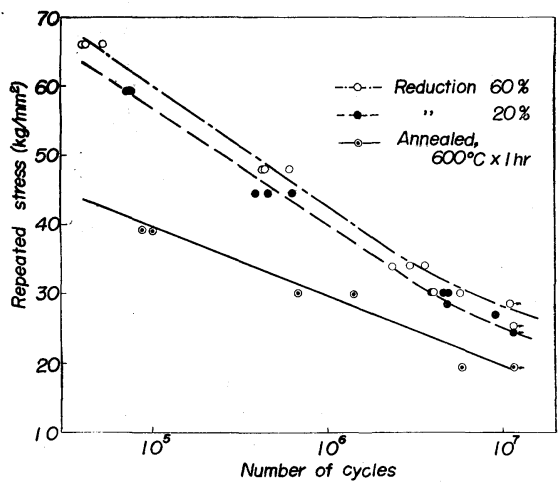

Fig. $8 S-N$ curves of nickel silver wire with various degrees of reduction
示したものである。曲線の傾きは加工度とともに大き くなる傾向があり, $10^{7}$ 回疲労強さも加工度とともに 増加しているのが認められる。 Fig. 9 は $10^{5}, 10^{6}, 10^{7}$ 時間疲労強さを示したもので，この場合でも各時間強 度は加工度とともに増加している。

\section{(III） 低温焼鈍による機械的性質}

Fig. 10 は加工度 $20 \%$ 試料の低温焼鈍後の引張強さ，

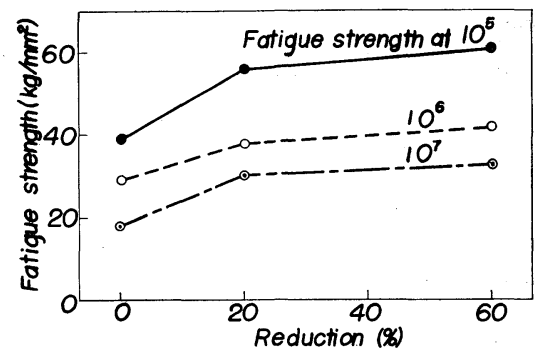

Fig. 9 Relation between the degree of reduction by cold drawing and the fatigue strength at $10^{5}, 10^{6}, 10^{7}$ cycles

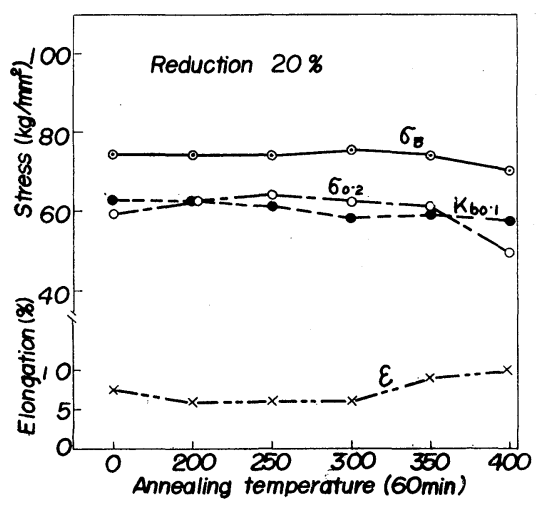

Fig. 10 Relation between the annealing temperature and the values of $\sigma_{B}, \sigma_{0} \cdot 2$ $K_{b}$ and $\varepsilon$

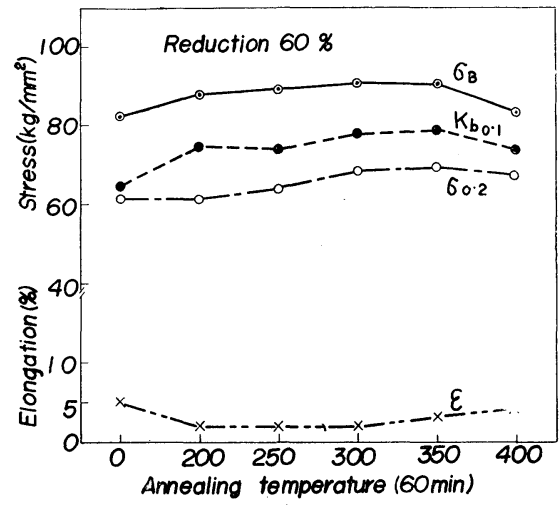

Fig. 11 Relation between the annealing temperature and the values of $\sigma_{B}, \sigma_{0} \cdot 2$ $K_{b}$ and $\varepsilon$ 
耐力, ばね限界值，伸びの結果を示したものである. これによると，いずれの特性にも低温焼鈍効果はみら れず，伸びは $350^{\circ} \mathrm{C}$ からずかずつ増加している。 た，Fig. 11 の加工度 $60 \%$ ものは，低温焼鈍温度 $250 \sim 350^{\circ} \mathrm{C}$ において引張強さ, 耐力, ばね限界值の 増加が認められる. Fig. 12 において加工度 $20 \%$ のも のは焼鈍温度の上温にしたがいかたさは逆に低下し， $400^{\circ} \mathrm{C}$ 付近では既に再結晶しはじめたものと思われる。 加工度 $60 \%$ のものは $250 \sim 350^{\circ} \mathrm{C}$ の範囲においてかな りの低温焼鈍効果が現われ，かたさ值はかなり増加し ている. Fig. 13 はねん回值を示し, 加工度 $20 \%$ も のにおいては $300^{\circ} \mathrm{C} て ゙$ 最小值が現われ，それ以上の温 度では再び増加する. 加工度 $60 \%$ ののは 300〜350 ${ }^{\circ} \mathrm{C}$ に最低值がある。

\section{(IV) 低温焼鈍による疲労強さ}

Fig. 14, Fig. 15 は加工度 $20,60 \%$ 各焼鈍温度に

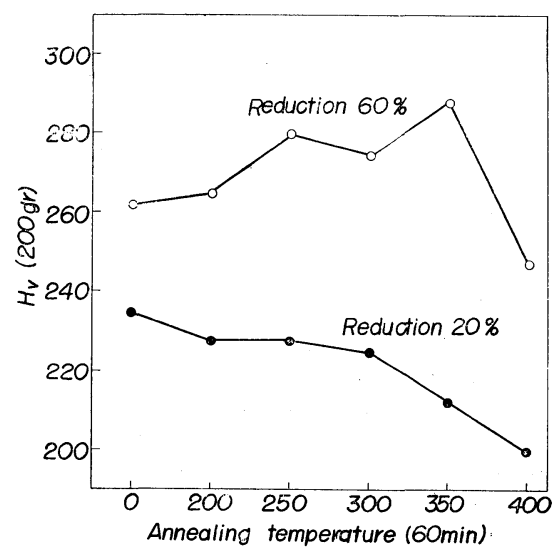

Fig. 12 Relation between the annealing temperature and hardness

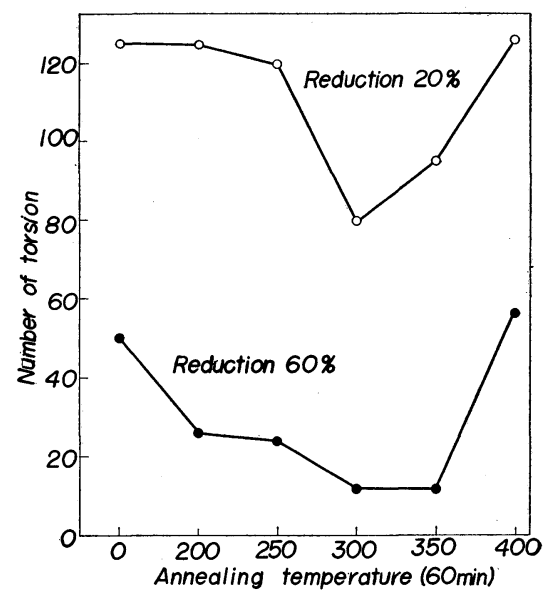

Fig. 13 Relation between the annealing temperature and the number of torsion
よる $S-N$ 曲線の結果を示す。これによると曲線の傾 向は加工材とは異なり, 比較的ゆるやかである. 特に $20 \%$ 加工のものは, 各温度において曲線の傾きや時間 疲労強度ともかなり接近した值を示している. $60 \%$ 加 工の曲線の傾きは $20 \%$ 加工よりややきびしくなり， 時間疲労強度も各温度において差異がある. Fig. 16 は $20 \%$ 加工の各焼鈍温度による $10^{5}, 10^{6}, 10^{7}$ 時間疲 労強さを示したものである. 各温度間には疲労強さの 増加はみられないが，特に $10^{6}, 10^{7}$ 疲労強さは加工の

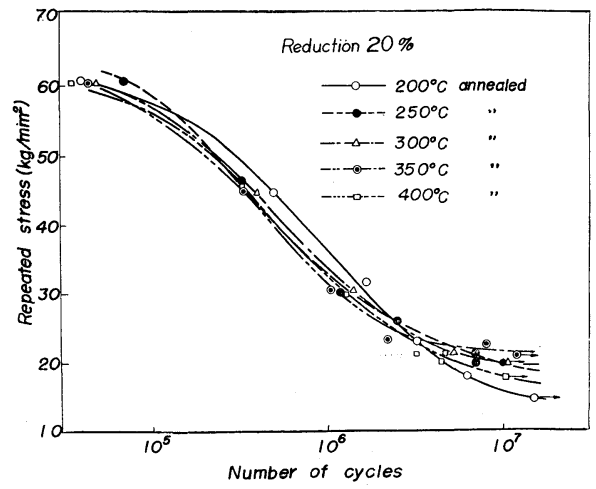

Fig. $14 S-N$ curves of nickel'silver wire with various annealing temperature

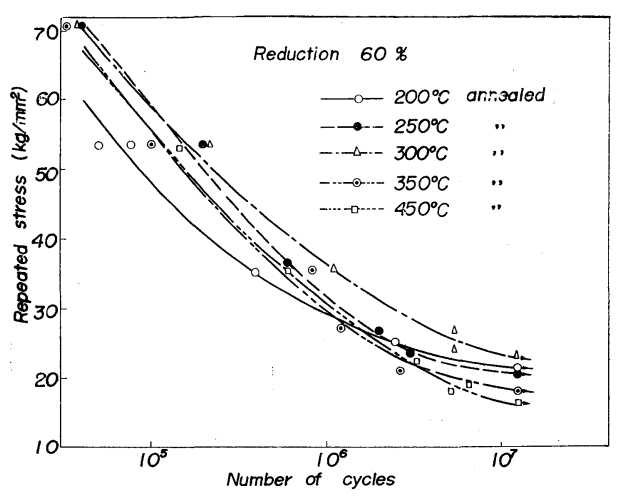

Fig. $15 S-N$ curves of nickel silver wire with various annealing temperature

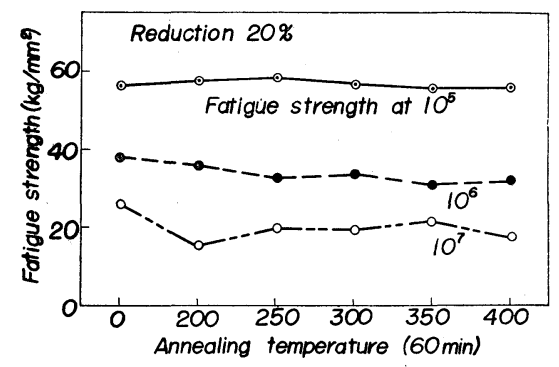

Fig. 16 Relation between the annealing temperature and the values fatigue strength at $10^{5}, 10^{6}, 10^{7}$ cycles 
ままより低下している. Fig. 17 の加工度 $60 \%$ のの は $300^{\circ} \mathrm{C}$ に疲労強さの最大值が認められるが, 加工の ままの疲労強さより低い. Table 2 は以上の加工およ び焼鈍しによる引張強さ, 伸び, 耐力, ばね限界值, ねん回值, かたさ, 各時間疲労強さ, 疲労限度比の結 果をまとめたものである.この表より疲労限度比 $(k=$ $\left.\sigma_{w^{\prime}} / \sigma_{B}\right)$ をみると, 繰返数 $10^{7}$ 回おいては加工材で約 $0 \cdot 35$, 低温焼鈍材で約 0.25 ぐらいであり, 直線性加 工した洋白線は低温焼鈍による疲労強さの増加は期待 できない。また，他の機械的性質と疲労強さには明ら かな関係はみられない。

\section{4. 結}

\section{論}

ばね用洋白線について冷間加工（直線性加工も含む） および暁鈍しによる引張強さ，耐力，伸び，ばね限界 值, かたさ, ねん回值と回転曲げ疲労強さの変化を調 べて次の結果を得た。

（1）洋白線は冷間加工により, 引張強さ, 耐力,

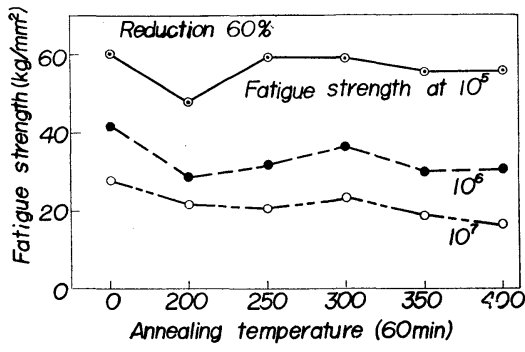

Fig. 17 Relation between the annealing temperature and the values fatigue strength at $10^{5}, 10^{6}, 10^{7}$ cycles
ばね限界值, かたさ, 疲労強さは増加し, 伸びは減少 する。ねん回值は，加工度 $20 \%$ 付近に最高值を示す。

（2）低加工材 (20\%加工度) に低温焼鈍し (200〜 $\left.400^{\circ} \mathrm{C} \times 60 \mathrm{~min}\right)$ を行なっても，引張強さ，耐力，ば ね限界值は増加しない，功さは焼鈍温度の上昇とと もに低下し， $400^{\circ} \mathrm{C}$ 付近から軟化が開始される。ねん 回値は $300^{\circ} \mathrm{C}$ に最低值がある。

（3）高加工材 (60\%加工度) に低温焼鈍しを行な うと $250 \sim 350^{\circ} \mathrm{C}$ において引張強さ，耐力，ばね限界 值, 疲労強さの増加がみられるが, 疲労強さは加工の ままより低い，功は $250 \sim 350^{\circ} \mathrm{C}$ において急激に 増加する。ねん回值はこの温度範囲では最低值を示す。

（4）洋白線の疲労限度比 $\left(k=\sigma_{w^{\prime}} / \sigma_{B}\right)$ は, 冷間加 工材で $0 \cdot 35$, 低温焼鈍材で約 0.25 であり, 直線加工 したものは低温焼鈍しによる疲労強さの増加はない。

（5）ばね限界值は引張試験より求めた耐力に相応 する。

終りにのぞみ, 電気通信研究所早坂次長, 寉小谷調 査役, ならびに東京大学吉沢教授の御指導に深甚なる 感謝の意を表わすとともに，試料の加工熱処理に終始 お世話いただいた仲田研究主任，三菱電気 KK世田谷 工場に厚く御礼申し上げます。

\section{参 考 文 献}

1）仲田，通研月報，6， No.4（1953)

2) バネ協会, バネ, p.71 (1958)

3）太郎良，日本金属学会誌，15 A, No. 8, No. 9, No. 10 (1951)

4) 武井, 日本金属学会誌, 21，4，217 (1957)

5） 7） 仲田, 通研究実用化報告, 7, No. 5 (1958)

8) 坂本, 材料誠験, 5, 35, 470 (1956)

Table 2 Total relations between the measured mechanical properties and fatigue strength in nickel silver wire

\begin{tabular}{|c|c|c|c|c|c|c|c|c|c|c|c|c|c|}
\hline \multirow{2}{*}{$\begin{array}{c}\text { Reduction } \\
(\%) \\
\end{array}$} & \multirow{2}{*}{$\begin{array}{l}\text { Annealing } \\
\text { tempera- } \\
\text { ture } \\
(\times 60 \mathrm{~min})\end{array}$} & \multirow{2}{*}{$\begin{array}{c}H_{V} \\
(200 \mathrm{gr})\end{array}$} & \multirow{2}{*}{$\begin{array}{c}\text { Yield } \\
\text { strength } \\
\left(0^{\circ} 2\right) \\
\left(\mathrm{kg} / \mathrm{mm}^{2}\right)\end{array}$} & \multirow{2}{*}{$\begin{array}{c}\text { Tensile } \\
\text { strength } \\
\left(\mathrm{kg} / \mathrm{mm}^{2}\right)\end{array}$} & \multirow{2}{*}{$\begin{array}{c}\text { Elon- } \\
\text { gation } \\
(\%)\end{array}$} & \multirow{2}{*}{$\begin{array}{l}\text { Num. } \\
\text { ber } \\
\text { of } \\
\text { torsion }\end{array}$} & \multirow{2}{*}{$\begin{array}{c}K_{b} 0.1 \\
\left(\mathrm{~kg} / \mathrm{mm}^{2}\right)\end{array}$} & \multicolumn{3}{|c|}{$\begin{array}{c}\text { Fatigue strength } \\
\left(\mathrm{kg} / \mathrm{mm}^{2}\right)\end{array}$} & \multicolumn{3}{|c|}{$\begin{array}{c}\text { Fatigue ratio } \\
\left(\begin{array}{c}\text { Fatigue strength } \\
\text { Tensile strength }\end{array}\right)\end{array}$} \\
\hline & & & & & & & & $10^{5}$ & $10^{6}$ & $10^{7}$ & $10^{5}$ & $10^{6}$ & $10^{7}$ \\
\hline \multirow{6}{*}{20} & 0 & 235 & $59 \cdot 5$ & $74 \cdot 5$ & $7 \cdot 8$ & 125 & $63 \cdot 0$ & $56^{\circ} 4$ & $38 \cdot 4$ & $26 \cdot 0$ & 0.76 & 0.52 & 0.35 \\
\hline & 200 & 228 & 63.0 & $74 \cdot 2$ & 6.0 & 125 & $63 \cdot 0$ & $57 \cdot 5$ & $36^{\circ} 0$ & $15 \cdot 5$ & 0.77 & 0.48 & 0.20 \\
\hline & 250 & 228 & $64 \cdot 6$ & $74 \cdot 2$ & 6.0 & 120 & $62 \cdot 0$ & $58 \cdot 5$ & $33 \cdot 0$ & $20 \cdot 0$ & 0.78 & 0.44 & 0.26 \\
\hline & 300 & 225 & 63.0 & $75 \cdot 8$ & 6.0 & 80 & $59^{\circ} 0$ & $57 \cdot 0$ & $34^{\circ} 0$ & $19 \cdot 5$ & 0.75 & 0.44 & 0.25 \\
\hline & 350 & 212 & $61 \cdot 5$ & $74 \cdot 8$ & $9 \cdot 0$ & 95 & $59 \cdot 5$ & $56^{\circ} 0$ & $31 \cdot 5$ & $21 \cdot 5$ & 0.74 & 0.42 & 0.28 \\
\hline & 400 & 200 & $55 \cdot 1$ & 70.4 & 10.0 & 126 & $58^{\circ} 0$ & $56 \cdot 5$ & $32 \cdot 5$ & $18 \cdot 0$ & 0.80 & 0.46 & 0.25 \\
\hline \multirow{6}{*}{60} & 0 & 260 & $61 \cdot 4$ & $82 \cdot 8$ & $5 \cdot 1$ & 50 & $65^{\circ} 0$ & 60.8 & $42 \cdot 0$ & $28 \cdot 0$ & 0.73 & 0.50 & 0.33 \\
\hline & 200 & 264 & $61 \cdot 5$ & $88 \cdot 2$ & $2 \cdot 0$ & 26 & $75^{\circ} 0$ & $48 \cdot 0$ & $29 \cdot 0$ & $22 \cdot 0$ & 0.54 & 0.32 & 0.24 \\
\hline & 250 & 280 & $64 \cdot 3$ & $88 \cdot 5$ & $2 \cdot 0$ & 24 & $74^{\circ} 0$ & $59 \cdot 5$ & $32 \cdot 0$ & $21 \cdot 0$ & 0.67 & 0.36 & 0.23 \\
\hline & 300 & 274 & $68 \cdot 5$ & 90.8 & $2 \cdot 0$ & 12 & $78^{\circ} 0$ & $59 \cdot 0$ & $36 \cdot 5$ & $23 \cdot 5$ & 0.64 & 0.40 & 0.25 \\
\hline & 350 & 288 & $69 \cdot 4$ & $90 \cdot 4$ & $3 \cdot 0$ & 12 & $78 \cdot 5$ & $55 \cdot 5$ & 30.0 & $18 \cdot 5$ & 0.61 & 0.33 & 0.20 \\
\hline & 400 & 247 & $67 \cdot 8$ & $83 \cdot 8$ & $4 \cdot 0$ & 56 & $74 \cdot 5$ & $56^{\circ} 0$ & 30.5 & $16 \cdot 5$ & 0.66 & 0.36 & 0.19 \\
\hline \multicolumn{2}{|c|}{$600^{\circ} \mathrm{C} \times 1 \mathrm{hr}$ annealed } & 114 & $27 \cdot 7$ & $54 \cdot 5$ & $35 \cdot 0$ & 50 & $33 \cdot 0$ & $39 \cdot 6$ & $29 \cdot 0$ & $18 \cdot 8$ & $0 \cdot 73$ & 0.53 & 0.34 \\
\hline
\end{tabular}

